University of Wollongong

Research Online

Faculty of Law, Humanities and the Arts Papers (Archive)

Faculty of Arts, Social Sciences \& Humanities

$1-1-2019$

Controlling the clock-how showing and telling impact time in short-short fiction

Shady E. Cosgrove

University of Wollongong, shady@uow.edu.au

Follow this and additional works at: https://ro.uow.edu.au/lhapapers

Part of the Arts and Humanities Commons, and the Law Commons

Research Online is the open access institutional repository for the University of Wollongong. For further information contact the UOW Library: research-pubs@uow.edu.au 


\title{
Controlling the clock-how showing and telling impact time in short-short fiction
}

\author{
Abstract \\ 'Show, don't tell' is a common axiom in creative writing classes but the short-short story form complicates \\ this idea. Often, in micro- and flash fiction it is through telling and implication that showing occurs. Taking \\ that into account, I will argue that in the micro- and flash context, where brevity defines the narrative \\ parameters, the relationship between showing and telling is one connected to pacing and the narrative \\ construction of time. That is, what the author chooses to show and tell often impacts on the \\ representation of temporality. This will be explored critically and creatively via case studies 'Insect \\ Wisdom' and 'Note to Self'. \\ Disciplines \\ Arts and Humanities I Law \\ Publication Details \\ Cosgrove, S. "Controlling the clock-how showing and telling impact time in short-short fiction." New \\ Writing: the international journal for the practice and theory of creative writing Online First (2019): 1-6.
}




\title{
Controlling the clock - how showing and telling impact time in short- short fiction
}

By Shady Cosgrove, UOW

\begin{abstract}
Show, don't tell' is a common axiom in creative writing classes but the shortshort story form complicates this idea. Often, in micro- and flash fiction it is through telling and implication that showing occurs. Taking that into account, I will argue that in the micro- and flash context, where brevity defines the narrative parameters, the relationship between showing and telling is one connected to pacing and the narrative construction of time. That is, what the author chooses to show and tell often impacts on the representation of temporality. This will be explored critically and creatively via case studies 'Insect Wisdom' and 'Note to Self'. Keywords: micro-fiction, temporality, narratology, creative writing
\end{abstract}

\section{BREVITY AND IMPLICATION}

'Show, don't tell' is a common axiom in creative writing classes but the short-short story form complicates this idea because there simply isn't time for the writer to show multiple events taking place. Consider the microfiction, a short story form generally defined as 250 words or less. With the word-limit constraint, the author has no choice but to let telling and implication carry much of the story. As writer Charles Johnson says, 'the short-short demands compression and economy' $(1986,233)$. The microfiction author has a few paragraphs at most to pull off a beginning, a middle and an end, and every word must count.

Some microfiction theorists, like William Nelles (2012) argue that this brevity translates into an increased focus on plot - something needs to happen and it needs to happen fast. And while this is often true, I am wary of disregarding notions of character in this context. Take Susan McCreery's 173-word story 'Hold-Up' $(2014,21)$ where the tension of the story rests on the cashier recognising the gunman. It is the character 
details - the gunman once shared his fish paste sandwiches with the cashier at school that give dramatic weight to the action of the hold-up. And indeed, in many short-short works, it is the resonance of detail that adds emotional heft.

The use of detail can be an important narrative strategy for microfiction writers, however it is important the detail is carefully considered. In the short-short context, where every word must be critical to the story, specific detail should operate to give the reader a larger sense of the world and characters being depicted. Well-chosen description can imply more than it directly states. Writer Fred Chappell says: ‘...this form does not create a world in the way that a poem or short story may do; rather, it inhabits a larger world which it must take pains to imply’ $(1986,227)$. Writer Leonard Michaels agrees that the microfiction 'depend(s) immensely on implication' $(1986,233)$ and Oates says, 'in the smallest, rightest spaces, experience can only be suggested (1986, 247).

This could mean there is more space for reader interpretation with the microfiction than with other genres. Writer Robert Kelly directly sites the reader when he says that writing short-short fiction involves 'deft excision of what the reader expects, but does not need, to be told' $(1986,240)$. And Welsh writer Vanessa Gebbie takes this point further, drawing attention to the cooperative nature of what is written and read in microfiction (2012):

The reader engages to the extent that she fills in the spaces, and the reading experience becomes much more of a joint effort in which the reader and writer are in effect working closely together to create something larger than the word count.

Writer Hisham Bustani (2012) also advocates for the reader by saying it is the writer's job is to issue possibilities, as opposed to outcomes:

I think quantum physics and flash fiction are closely related. Werner Heisenberg, the scientist credited with conceptualizing the uncertainty principle, 
says, 'The atoms or elementary particles themselves are not real; they form a world of potentialities or possibilities rather than one of things or facts." That relates strongly to flash fiction...

That is, it is the job of the microfiction writer to suggest possibilities in their work, to imply larger potentialities that might exist beyond the page. The reader is then complicit in the reading/writing of the text because there is space for their imagining of events.

How far can this be taken, though? Writer Mark Strand ambitiously says the microfiction 'can do in a page what a novel does in two hundred' $(1986,247)$. And Paul Theroux says the short-short story 'is highly calculated - its effects, its timing. In most cases it contains a novel' $(1986,228)$. Hyperbole aside, Strand and Theroux signal that the microfiction can contain much more 'story' than its word count might imply. And because of word counts, this story must be told, not shown, as literary theorist Adam Rovner asserts: 'Summary in microfiction is not merely connective tissue, but the essential tissue that comprises the narrative form itself' $(2015,112)$.

\section{SHOWING AND TELLING, IMPLICATION AND TEMPORALITY}

I have established that the microfiction's necessity for brevity often leads to implication, and this can leave space for reader imagination. Brevity affects the scope of what an author can tackle (how much can happen) as well as how the story is told, specifically how showing and telling operate on the line-by-line level. That is, an author must choose which events are summarized (told) and which ones are dramatized (shown). The more events that take place in a microfiction, the more the author must rely on summary. Minimal word counts demand frugality with how much showing/description can be included in the text. Consider the following: 'I walked to the video store at night, pushing the baby in a pram.' The information is summarized for the reader in eleven 
words. In the short-short story 'A trip to the video store, when they still existed' about a new mother's first trip outside, this same information is imparted in 144 words:

It's only seven o'clock but night has fallen, certain as a blanket. It takes some figuring but I negotiate the stroller down the front step and past the mailbox, gliding onto the shimmery street. Rain, it must have rained. One of the lights twitch above, and the humidity hugs close but you're not crying. There's no sidewalk so I skim outside parked cars, listening for traffic, amazed by the concrete, the weatherboard, the power lines: they still exist. We pass the train station and commuters flock down the steps, otherworldly with purpose. Every bump in the road reverberates up my arms but we keep going. Around a corner, along the straight stretch until at last I pull into the parking lot. The windows are lined with movie posters, illuminated in florescent light, and I hear you call out. Both of us, giddy with accomplishment. (Cosgrove, 2018)

In the second version, considerably more description and detail is given to the experience of walking to the video store. For instance, the reader is told that it has recently rained, it is humid, the neighbourhood has weatherboard houses, there is a train station, etcetera. The author must decide how much description/detail to include and prioritise this detail in accordance with the text's themes. If the walk to the video store is only one minor incident in a much larger story, it would not make sense to give it so much space.

Decisions made in regards to showing and telling also affect the way time operates within a narrative. As writer and literary theorist Anthony Macris states (14) 'the acceleration or deceleration of time will affect: how the action is narrated (for example accelerations in narration will usually result in summary)'. We can see this demonstrated in the example above. 'I walked to the video store at night, pushing the baby in a pram' moves at a faster pace than the more descriptive excerpt. That is, the reader gets to the video store in six words, and the only specific detail is that the narrator is pushing a pram. The use of description slows the temporal schema. For example, the statement 'It takes some figuring but I negotiate the stroller down the front steps' implies a temporal progression via the word 'figuring'. The narrator walks past 
cars, then the train station, and the journey takes longer with these details. Even adverbial signifiers like 'keep' and 'at last' offer a sense of temporality - it takes time for the narrator to make the trek to the video store. This passing of time adds to the narrative's suspense. Generally, the more detail, the longer it takes for the reader to read, and the slower narrative time moves.

\section{CREATIVE CASE STUDIES}

In light of this discussion, I will read two further microfictions as case studies, paying attention to how the texts use implication, telling (summarizing) and showing (dramatizing) within the text, and how this affects their temporal schemas.

\footnotetext{
Insect wisdom

I was gripped with manuscript panic, so I ventured into the backyard for perspective and sunlight. Three paces from the door and a giant bug swooped. It was five metres across, prehistoric, all wings and fang, ant-beetle-wasp. I was caught between pincers, hung upside-down. My husband stood on the stoop, concerned. Our seven-year-old waved, eyeing off the antennas and bulbous eyes, but his dad sighed, ushering him inside for trombone practice and bath time. I stayed out there, suspended above the grass. Days passed. Weeks. The neighbour's dog finally shut up. And when I too accepted my precarity, the fierce grip around my torso relaxed and I toppled to the ground. (Cosgrove, 2018)
}

'I was gripped with manuscript panic' is a direct statement. The reader is not given detail about what precipitated this panic, but any practising writer can imagine what this entails - doubt with the writing process, fear that the project has gone off-course, fear that it never was on course, fear of being published, fear of never being published. The entire story is about negotiating with that panic, but at no place is the reader given the specificity of the narrator's writing project. Instead, we are grounded in the metaphor of a large ant-beetle-wasp swooping onto the narrator, grabbing her between pincers, and the two of them at an impasse, in the back yard, as weeks pass. We are told the premise 
of the story and shown the metaphoric implications as opposed to actual ones. This leaves space for the reader to decide what, exactly, 'manuscript panic' means. It also leaves space for the reader to decide how long the narrator has been wrestling with this manuscript panic. That is, this use of implication also plays out with regards to the temporal schema leading into the story.

With regards to the narrator's domestic situation, we are given clues in the detail: there is a husband and 'our' seven-year old so the reader can assume this is a long-term relationship. The husband is concerned about the giant insect but he sighs, taking the child inside for trombone practice and bath time, implying this has happened before. Both of these facts highlight the passage of time, and they are both established via implication. That is, the microfiction does not 'create' a world, as Fred Chappell stated above, it is inhabiting a larger world that is established via implication and the passage of time is integral to that.

In a story with only eleven sentences all up, six of those are dedicated to the initial experience of being grabbed by a large bug and having that textual space dedicated to one action gives it narrative weight. The detail slows the pace - the reader witnesses the experience of the pincers, the ant-beetle-wasp, however the pacing then shifts abruptly within the span of three words, 'Days passed. Weeks' and the reader understands the narrator has been hung upside-down for a fortnight, maybe as long as a month. Together with the use of past tense, it is obvious the recounter is positioned after events have taken place. The narrator has perspective. Details demonstrate the passage of time as well, such as 'The neighbour's dog finally shut up.' The adverbial signifier 'finally' indicates time has passed: even this loudmouth canine has calmed down. The narrator then 'accept[s her] precarity' and a progression is implied by placing that 
sentence after the neighbour's dog (using of the word 'too'). When the dog had calmed down, finally too did the narrator.

My point in this analysis is to demonstrate how implication plays out in microfiction and how that implication is bound up with the representation of time, within the short-short text. My next example is more extreme in light of implication, aligned with Hemingway's 'For sale. Baby shoes: never worn.'

\section{Note to self:}

Don't fill your thermos with red wine for the school picnic. (Cosgrove, 2018)

This story operates almost entirely via implication. The title tells the reader the narrator is making a note to self and the text that follows is a directive. The reader is given the setting: a school picnic. However, the reader is not given any specificity with regards to the kind of school that it is, or where the school picnic has been held. The 'climax' of this story is not even articulated. The reader assumes that something has transpired in relation to an intoxicated narrator because of the juxtaposition of the 'Note to Self' with the red wine, and whatever it is that has occurred has led to embarrassing and/or undesired results. The reader is not given any detail - perhaps the narrator accosted a principal or hit on a kindergarten teacher. Maybe they shouted at a parent or smacked a misbehaving child who was not theirs. Whatever it is that has taken place, the reader is entirely left to imagine the events. Interestingly, too, in this story the reader is not given a protagonist. The 'Note to self' could be someone else's directive, or it could be the reader's, especially as second person is used: 'your thermos'.

Because there is so little text, and the story is left to the reader's imagination, time becomes fluid, and the reader is left to determine how intricate and long the events 
are which have led the narrator to establish this 'Note to self'. The important details, however, are the thermos, the red wine and the school picnic. Those three nouns operate together with the title to imply a series of plotted events - this is where the tension of the story rests. If plot is a causal sequence of events, then as soon as we have the existence of event, we have an underlying assumption of time because in order for multiple events to take place, we must have the existence of a temporal schema that orders them.

In conclusion, this paper has explored the use of detail and implication as a strategy for world and story-building in microfiction, and this has reverberations for the way time operates in the text. I have examined examples of my own creative work, where implication has been foregrounded, and performed close textual readings, arguing that detail can influence how the microfiction's larger temporal schema operates. It is my hope this can provide new ways of thinking about detail as a temporal device for microfiction writers as they grapple with the word-limit constraints of the form. 


\section{REFERENCES}

Bustani, Hisham. 2012. Interviewed in 'The Very Short Q\&A on Very Short Fiction' World Literature Today. September 2012. Online publication. https://www.worldliteraturetoday.org/2012/september/very-short-qa-very-short-fiction (accessed on September 20, 2018).

Chappell, Fred. 1986. 'The Tradition.' In Sudden Fiction American Short-Short Stories, edited by Robert Shapard and James Thomas, 227. Layton: Gibbs Smith Publishers.

Cosgrove, Shady. 2018. 'Insect Wisdom' Cordite Poetry Review. Melbourne.

http://cordite.org.au/poetry/suburbia/insect-wisdom/ (accessed on September 20, 2018).

2018. 'A trip to the video store, when they still existed' (written for this article).

2018. 'Note to Self' (written for this article).

Gebbie, Vanessa. 2012. Interviewed in 'The Very Short Q\&A on Very Short Fiction' World Literature Today. September 2012. Online publication. https://www.worldliteraturetoday.org/2012/september/very-short-qa-very-short-fiction (accessed on September 20, 2018).

Johnson, Charles. 1986. 'The Tradition.' Sudden Fiction American Short-Short Stories, edited by Robert Shapard and James Thomas, 233. Layton: Gibbs Smith Publishers.

Kelly, Robert. 1986. “Toward a New Form.' Sudden Fiction American Short-Short Stories, edited by Robert Shapard and James Thomas, 240. Layton: Gibbs Smith Publishers.

Macris, Anthony. 2018 'Macrostructure and local schemas in the practice of novelistic narrative.' New Writing. 12 July 2018: 1-17. doi: 10.1080/14790726.2018.1490777

McCreery, Susan. 2014. 'Hold Up.' Flashing the Square, edited by Linda Godfrey and Bronwyn Mehan. Strawberry Hills: Spineless Wonders.

Michaels, Leonard. 1986. 'The Tradition.' Sudden Fiction American Short-Short Stories, edited by Robert Shapard and James Thomas, 233. Layton: Gibbs Smith Publishers.

Nelles, William. 2012, "Microfiction: What Makes a Very Short Story Very Short?" in Narrative 20.1: 87-104. Print.

Oates, Joyce Carol. 1986. 'Toward a New Form.' Sudden Fiction American Short-Short Stories, edited by Robert Shapard and James Thomas, 247. Layton: Gibbs Smith Publishers.

Rovner, Adam. 2015. 'The Shape of Time in Microfiction: Alex Epstien and the Search for Lost Time.' Shofar: an Interdisciplinary Journal of Jewish Studies. 3.4: 111-133.

Royle, Nicholas. 2014. 'Quick Fiction: Some Remarks on Writing Today.' Mosaic. 47.1: 23-39. 
Strand, Mark. 1986. 'Toward a New Form.' Sudden Fiction American Short-Short Stories, edited by Robert Shapard and James Thomas, 247. Layton: Gibbs Smith Publishers.

Theroux, Paul. 'The Tradition.' Sudden Fiction American Short-Short Stories, edited by Robert Shapard and James Thomas, 228. Layton: Gibbs Smith Publishers. 